\title{
Pengaruh Internet Banking Terhadap Minat Nasabah Dalam Bertransaksi Dengan Technology Acceptance Model
}

\author{
Evi Yani ${ }^{1}$, Ade Fitria Lestari ${ }^{2}$, Hilda Amalia ${ }^{3}$, Ari Puspita ${ }^{4}$ \\ ${ }^{1}$ STMIK Nusa Mandiri Jakarta \\ email: viyaviyaviyaibu@gmail.com \\ ${ }^{2}$ AMIK BSI Jakarta \\ email: ade.afr@bsi.ac.id \\ ${ }^{3}$ AMIK BSI Jakarta \\ email: hilda.ham@bsi.ac.id \\ ${ }^{4}$ STMIK Antar Bangsa \\ email: ari.puspita@gmail.com
}

\begin{abstract}
Abstrak
Internet banking merupakan salah satu teknologi transaksi perbankan yang ditawarkan oleh bank-bank komersial di Indonesia untuk para nasabah dalam melakukan transaksi seperti transfer, pembayaran, dan sebagainya dengan mudah dan cepat. Sebagian besar nasabah lebih memilih melakukan transaksi dengan internet banking dibandingkan harus mendatangi ke bank, hal ini berdasarkan OJK (Otoritas Jasa Keuangan) mencatat bahwa jumlah pengguna ebanking meningkat sebesar $270 \%$ dari 13,6 juta nasabah pada tahun 2012 menjadi 50,4 juta nasabah pada tahun 2016. Peningkatan terjadi dikarenakan adanya kebutuhan masyarakat dalam memanfaatkan teknologi. Penelitian ini bertujuan untuk mengetahui pengaruh internet banking terhadap minat nasabah dengan TAM (Technology Acceptance Model)yaitu persepsi kemudahan dan persepsi kegunaan. Metode pengumpulan data dengan kuesioner secara random sampling sebanyak 104 responden nasabah BRI dengan menggunakan skala Likert, pengujian data melalui uji validitas, reabilitas, normalitas, linearitas, uji regresi dan koefisien determinasi dan pengolahan kuesioner dengan SPSS. Hasil penelitian menunjukkan bahwa persepsi kemanfaatan penggunaan internet banking terhadap persepsi kemudahan dalam bertransaksi bagi nasabah Bank BRI.Semakin banyak manfaat yang dirasakan para nasabah,maka akan mempengaruhi kemudahan bagi nasabah setiap bertransaksi menggunakan internet banking.
\end{abstract}

Kata Kunci: Internet banking, Technology Acceptance Model, persepsi kemudahan, persepsi kegunaan.

\begin{abstract}
Internet banking is one of the banking transaction technology offered by commercial banks in Indonesia for customers in transactions such as transfers, payments, and so on easily and quickly. Most customers prefer to make transactions with internet banking rather than go to banks, according to OJK (Financial Services Authority) noting that the number of e-banking users increased by $270 \%$ from 13.6 million customers in 2012 to 50.4 million customers in the year 2016. Increases occur due to the needs of the community in utilizing technology. This study aims to determine the effect of internet banking on customer interest with TAM (Technology Acceptance Model) that is perception of ease and perception of usability. Methods of collecting data with questioner by random sampling of 104 respondents of BRI customers by using Likert scale, testing data through validity test, reliability, normality, linearity, regression test and coefficient of determination and questionnaire processing with SPSS. The results showed that the perception of the usefulness of internet banking usage on the perception of ease in
\end{abstract}


transactions for customers of Bank BRI. The more benefits perceived by customers, it will affect the convenience for every customer to transact using internet banking.

Keywords : Internet banking, Technology Acceptance Model, perceived ease of use, perceived usefulness

\section{Pendahuluan}

Internet Banking merupakan salah satu bentuk produk jasa yang mulai banyak ditawarkan oleh bank-bank komersial di indonesia. Pada saat ini penggunaan Internet-Banking bagi nasabah meluas karena memberikan manfaat yang sangat besar bagi kelancaran proses-proses transaksi. proses transfer, penarikan, dan pembayaran transaksi yang dilakukan melalui Internet-Banking akan mempermudah dan mempercepat penyelesaian transaksi tersebut.

Salah satu produk berbasis internet yang saat ini menjadi perhatian dikalangan perbankan dunia adalah internet banking. (Chan \& M, 2004)

Internet banking memberikan solusi penghematan biaya operasional (cost effective) dalam penggunaannya dibandingkan dengan saluran lainnya. Dikarenakan internet banking mampu mengurangi biaya transaksi ke titik terendah yaitu dapat menghemat $79 \%$ biaya dibandingkan dengan biaya transaksi perbankan yang lainnya. (Sanusi, 2000)

Banyak layanan yang telah ditawarkan pihak bank kepada nasabah dalam hal ini seperti sms banking, mobile banking, Berdasarkan OJK (Otoritas Jasa Keuangan) mencatat bahwa jumlah pengguna e-banking meningkat sebesar $270 \%$ dari 13,6 juta nasabah pada tahun 2012 menjadi 50,4 juta nasabah pada tahun 2016. Peningkatan terjadi dikarenakan adanya kebutuhan masyarakat dalam memanfaatkan teknologi.

Internet banking adalah nasabah BRI KCP Unit Jagakarsa dengan berbagai kemudahan dan kelebihan dalam melakukan transaksi, tetapi banyak pula nasabah yang lebih memilih untuk melakukan transaksi dengan langsung mendatangi kantor bank baik kantor cabang maupun kantor pusat bank yang bersangkutan. Hal ini menimbulkan sudut pandang yang berbeda dalam persepsi manfaat yang diterima nasabah melalui layanan Internet banking. Pada dasarnya, sebuah layanan yang mampu memberikan manfaat pada nasabah pasti akan diterima dengan baik.
Dalam laporan tahunan yang dikeluarkan APJII, bank BCA menjadi bank yang paling sering digunakan dalam transaksi internet banking, pada urutan kedua disusul oleh bank mandiri sedangkan ketiga dan keempat ditempati oleh bank BNI dan bank BRI. Data terbaru yang dikutip pada situs sharingvision.com (Selasa, 6 Desember 2016) bahwa Berdasarkan data pengguna dari 6 bank besar di Indonesia, pada tahun 2014 total jumlah pengguna Internet banking mencapai 10 juta pengguna. Menurut prediksi Sharing Vision, jumlah pengguna Internet banking akan meningkat hingga 12,2 juta pengguna.

Untuk mengetahui minat nasabah terhadap penggunaan internet banking dalam bertransaksi maka dilakukan penelitian dengan menggunakan model penerimaan teknologi (Technology Acceptance Model ) atau biasa disebut dengan model TAM dengan persepsi kemudahan dan kegunaan/manfaat.

Salah satu teori mengenai penggunaan sistem informasi yang dianggap sangat berpengaruh dan umumnya digunakan untuk menjelaskan penerimaan individual terhadap penggunaan system informasi adalah model penerimaan teknologi informasi Technology Acceptance Model (TAM). Technology Acceptance Model (TAM) merupakan suatu model penerimaan sistem informasi yang akan digunakan oleh pemakai (user). (Hartono, 2007)

Persepsi manfaat pengunaan merupakan sejauh mana seseorang percaya bahwa menggunakan suatu teknologi akan meningkatkan kinerja dari pekerjaannya. (Hartono, 2007)

Persepsi Kemudahan Penggunaan (Perceived Ease of Use) adalah persepsi kemudahan penggunaan berarti keyakinan individu bahwa menggunakan sistem teknologi informasi tidak akan merepotkan atau membutuhkan usaha yang besar pada saat digunakan (free of effort).

Minat perilaku (behavioral intention) adalah suatu keinginan atau minat seseorang untuk melakukan suatu perilaku tertentu. Minat berhubungan dengan perilaku-perilaku atau tindakan-tindakan, 
akan tetapi minat dapat berubah menurut waktu, semakin lebar interval waktu, semakin dimungkinkan terjadi perubahanperubahan minat seseorang. (Hartono, 2007)

Berdasarkan penelitian sebelumnya bahwa Tujuan utama dari penelitian ini adalah untuk menganalisis faktor-faktor yang mempengaruhi minat seorang nasabah untuk mau menggunakan Sistem Informasi Akuntansi Perbankan berupa Internet Banking dengan menggunakan Technology Acceptance Model (TAM). Selain itu, peneliti juga menambahkan konstruk laten berupa persepsi keamanan kedalam TAM. Objek dalam penelitian ini adalah nasabah Bank Central Asia yang ada di kota Palembang dengan pertimbangan bahwa Bank Central Asia merupakan Bank pelopor Internet Banking di Indonesia sejak tahun 2000 dan mempunyai volume transaksi perbankan yang tertinggi pada akhir tahun 2012 dibandingkan dengan Bank lainnya. Sebanyak 194 sampel diambil dan dianalisis dengan menggunakan Structual Equation Model (SEM). Hasilnya menunjukkan bahwa persepsi kegunaan, persepsi kemudahan penggunaan, persepsi keamanan, dan sikap berhubungan positif secara signifikan dengan minat nasabah Bank Central Asia di Kota Palembang untuk menggunakan Internet Banking. Selain itu juga ditemukan fenomena bahwa ternyata persepsi kegunaan tidak berpengaruh secara langsung terhadap minat, melainkan berpengaruh secara tidak langsung melalui sikap. Fenomena ini sebenarnya disebabkan oleh faktor demografis berupa perbedaan tempat dan waktu dilakukannya penelitian menjadi penyebab utama terjadinya perbedaan hasil penelitian ini dengan dasar teori yang ada dan penelitian terdahulu. (Gunawan, 2014)

Berdasarkan pemaparan hasil penelitian maka dapat disimpulkan terjadi pengaruh dari persepsi manfaat, persepsi kemudahan, keamanan, dan ketersediaan fitur terhadap minat ulang menggunakan internet banking secara signifikan. Artinya bahwa responden menyatakan semua variable bebas tersebut dianggap penting untuk dapat meningkatkan minatnya dalam menggunakan layanan internet banking. Berdasarkan hasil penelitian menunjukkan bahwa ada hipotesis yang tidak dapat diterima yang artinya bahwa secara parsial menunjukkan bahwa persepsi manfaat, keamanan dan ketersediaan fitur mempunyai pengaruh yang positif dan signifikan terhadap minat ulang menggunakan layanan internet banking, kecuali pada variabel persepsi kemudahan yang tidak mempunyai pengaruh yang signifikan terhadap minat ulang nasabah dalam menggunakan internet banking. (Ahmad \& Pambudi, 2014)

Aspek perilaku dalam pengadopsian teknologi informasi adalah sebuah hal penting untuk diperhatikan, karena interaksi antara pengguna dengan perangkat komputer merupakan hasil dari persepsi, sikap, afeksi, sebagai aspek keprilakuan yang ada pada diri individu sebagai pengguna. (Devi \& Suartana, 2014)

\section{Metode Penelitian}

Dalam penelitian ini, penulis melakukan tahapan penelitian sebagai berikut:

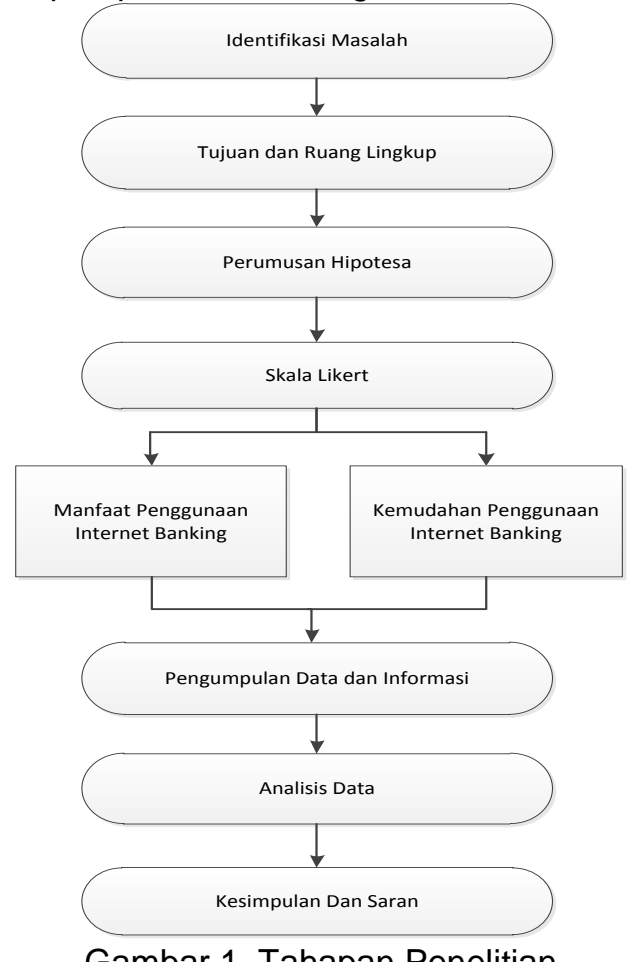

Gambar.1. Tahapan Penelitian

Sumber : Hasil Penelitian (2017)

\section{Metode Pengumpulan Data}

Dalam metode penelitian ini, penulis melakukan pengumpulan data dengan beberapa tahap yaitu :

a. Observasi

Melakukan pengumpulan data secara langsung melalui pengamatan objek penelitian yang berkaitan dengan adanya persepsi manfaat dan kemudahan nasabah dalam penggunaan Internet banking di BRI KCP Unit Jagakarsa. 
b. Wawancara

Melakukan tanya jawab secara tatap muka dengan pihak karyawan BRI KCP Unit Jagakarsa yang menjadi sumber informasi untuk mengetahui data nasabah BRI yang menggunakan fasilitas internet banking BRI.

c. Studi Pustaka

Penelitian yang dilakukan penulis untuk mempelajari serta mengumpulkan dan memperoleh data-data melalui studi pustaka teori yang berkaitan dengan objek penelitian dari berbagai sumber.

\section{Kuesioner}

Kuesioner yang ditujukan para nasabah BRI dalam bertransaksi menggunakan internet banking menggunakan skala likert.

\section{Populasi dan Sampel Penelitian}

Populasi diartikan sebagai wilayah generalisasi yang terdiri atas : objek/subyek yang mempunyai kualitas dan karakteristik tertentuyang ditetapkan oleh peneliti untuk dipelajari dan kemudian ditarik kesimpulannya. (Sugiyono, 2010). Sampel adalah sebagian atau wakil populasi yang diteliti. (Arikunto, 2010). Sampel adalah bagian dari jumlah dan karakeristik yang dimiliki oleh populasi tersebut. (Sugiyono, 2014)

Dalam penelitian ini, populasi yang diteliti adalah nasabah bank BRI KCP Unit Jagakarsa yang menggunakan internet banking dengan jumlah sampel yang diambil sebanyak 104 responden berdasarkan populasi 140 .

Metode Analisis Data

Analisis data kuantitatif digunakan jika data yang diperoleh dalam jumlah besar dan mudah diklasifikasikan dalam kategori-kategori atau diubah dalam bentuk angka-angka.

Uji distribusi normal adalah uji untuk mengukur apakah data kita memiliki distribusi normal sehingga dapat dipakai dalam statistik parametrik (statistik inferensial). Cara yang biasa dipakai untuk menghitung masalah ini adalah Chi Square. Tapi karena tes ini memiliki kelemahan, maka kita pakai adalah KolmogorofSmirnov.

Uji linearitas bertujuan untuk mengetahui apakah dua variabel mempunyai hubungan yang linear atau tidak. Uji tersebut digunakan sebagai prasyarat dalam analisis korelasi atau regresi linear. (Kasmadi \& Sunariah, 2014)

Analisa regresi sederhana digunakan untuk memprediksi variabel $Y$ dari variabel
$X 1$ dan memprediksi variabel $Y$ dari variabel $\mathrm{X} 2$. Analisis regresidigunakan untuk memprediksi variabel $Y$ jika salah satu variabel $X$ dimanipulasi.Teknik analisis regresi memakai teknik analisis varians.

Koefisien determinasi digunakan untuk menganalisis seberapa besar presentase variabel bebas terhadap variable terkait.Perhitungan koefisien determinasi dilakukan pada hubungan antara $\mathrm{X} 1$ dengan $\mathrm{Y}, \mathrm{X} 2$ dengan $\mathrm{Y}$, serta $X 1$ dan $X 2$ secara bersama-sama dengan $\mathrm{Y}$.

\section{Hasil dan Pembahasan}

Penelitian ini mengambil sampel 104 responden di bank BRI KCP Unit Jagakarsa. Pengujian yang dilakukan yaitu:

\subsection{Uji Validitas}

Konstruk adalah kerangka dari suatu konsep, validitas konstruk adalah validitas yang berkaitan dengan kesanggupan suatu alat ukur dalam mengukur pengertian suatu konsep yang diukurnya. (Siregar, 2015)

Validitas menunjukkan sejauh mana alat pengukur untuk mengukur apa yang diukur Valid tidaknya suatu item instrumen dapat diketahui dengan membandingkan indeks korelasi product moment Pearson pada level signifikansi 5\% dengan nilai tabelnya $(0.194, n=104)$. Bila nilai $r$ hitung yang didapatkan lebih besar dari $r$ tabel sebesar 0.194 maka item tersebut dinyatakan valid dan sebaliknya jika lebih rendah dari $r$ tabel dinyatakan tidak valid.

Tabel 1. Uji Validitas Instrumen Variabel X

\begin{tabular}{|l|c|c|}
\hline \multicolumn{2}{|c|}{} & X \\
\hline X1.1 & Pearson Correlation & .498 \\
\cline { 2 - 3 } & Sig. (2-tailed) & .000 \\
\cline { 2 - 3 } & N & 104 \\
\hline X1.2 & Pearson Correlation & .496 \\
\cline { 2 - 3 } & Sig. (2-tailed) & .000 \\
\cline { 2 - 3 } & N & 104 \\
\hline X1.3 & Pearson Correlation & .516 \\
\cline { 2 - 3 } & Sig. (2-tailed) & .000 \\
\hline X1.4 & N & 104 \\
\cline { 2 - 3 } & Pearson Correlation & .328 \\
\cline { 2 - 3 } & Sig. (2-tailed) & .001 \\
\hline X1.5 & N & 104 \\
\cline { 2 - 3 } & Pearson Correlation & .508 \\
\cline { 2 - 3 } & Sig. (2-tailed) & .000 \\
\hline X1.6 & N & 104 \\
\cline { 2 - 3 } & Pearson Correlation & .581 \\
\cline { 2 - 3 } & Sig. (2-tailed) & .000 \\
\hline X1.7 & N & 104 \\
\cline { 2 - 3 } & Pearson Correlation & .712 \\
\cline { 2 - 3 } & Sig. (2-tailed) & 104 \\
\hline & N & \\
\cline { 2 - 3 } & & .000 \\
\hline
\end{tabular}




\begin{tabular}{|c|c|c|}
\hline \multirow[t]{3}{*}{$\mathrm{X} 1.8$} & Pearson Correlation & .598 \\
\hline & Sig. (2-tailed) & .000 \\
\hline & $\mathrm{N}$ & 104 \\
\hline \multirow[t]{3}{*}{$\mathrm{X} 1.9$} & Pearson Correlation & .498 \\
\hline & Sig. (2-tailed) & .000 \\
\hline & $\mathrm{N}$ & 104 \\
\hline \multirow[t]{3}{*}{$\mathrm{X} 1.10$} & Pearson Correlation & .533 \\
\hline & Sig. (2-tailed) & .000 \\
\hline & $\mathrm{N}$ & 104 \\
\hline \multirow[t]{3}{*}{$\mathrm{X}$} & Pearson Correlation & 1 \\
\hline & Sig. (2-tailed) & \\
\hline & $\mathrm{N}$ & 104 \\
\hline
\end{tabular}

Sumber : Hasil Penelitian (2017)

Tabel 2. Hasil Pengujian Instrumen Variabel $X$

\begin{tabular}{|c|c|c|c|}
\hline Item & $\mathbf{R}$ & Sig. & Keterangan \\
\hline X1.1 & 0.498 & 0.000 & Valid \\
\hline X1.2 & 0.496 & 0.000 & Valid \\
\hline X1.3 & 0.516 & 0.000 & Valid \\
\hline X1.4 & 0.328 & 0.001 & Valid \\
\hline X1.5 & 0.508 & 0.000 & Valid \\
\hline X1.6 & 0.581 & 0.000 & Valid \\
\hline X1.7 & 0.712 & 0.000 & Valid \\
\hline X1.8 & 0.598 & 0.000 & Valid \\
\hline X1.9 & 0.498 & 0.000 & Valid \\
\hline X1.10 & 0.533 & 0.000 & Valid \\
\hline
\end{tabular}

Sumber : Hasil Penelitian (2017)

Dari tabel 2 diatas, didapatkan bahwa semua item dari variabel $X$ sudah valid. Terlihat dari nilai correlation $(r)$ untuk masing-masing item valid yang lebih besar dari nilai $r$ tabel sebesar 0.194, atau dengan nilai signifikansi yang lebih kecil dari 0.05. Oleh karena itu, maka dapat diambil 10 item sudah valid dan dapat digunakan untuk penelitian selanjutnya.

Tabel 3. Uji Validitas Instrumen Variabel Y

\begin{tabular}{|l|l|c|}
\hline \multicolumn{2}{|l|}{} & Y \\
\hline Y1.1 & $\begin{array}{l}\text { Pearson } \\
\text { Correlation }\end{array}$ & $.345^{*}$ \\
\cline { 2 - 3 } & Sig. (2-tailed) & .000 \\
\cline { 2 - 3 } & N & 104 \\
\hline Y1.2 & $\begin{array}{l}\text { Pearson } \\
\text { Correlation }\end{array}$ & $.576^{* \prime}$ \\
\cline { 2 - 3 } & Sig. (2-tailed) & .000 \\
\cline { 2 - 3 } & N & 104 \\
\hline Y1.3 & $\begin{array}{l}\text { Pearson } \\
\text { Correlation }\end{array}$ & $.651^{* \prime}$ \\
\cline { 2 - 3 } & Sig. (2-tailed) & .000 \\
\cline { 2 - 3 } & N & 104 \\
\hline Y1.4 & $\begin{array}{l}\text { Pearson } \\
\text { Correlation }\end{array}$ & .587 \\
\cline { 2 - 3 } & Sig. (2-tailed) & .000 \\
\cline { 2 - 3 } & N & 104 \\
\hline Y1.5 & $\begin{array}{l}\text { Pearson } \\
\text { Correlation }\end{array}$ & .592 \\
\cline { 2 - 3 } & Sig. (2-tailed) & .000 \\
\hline
\end{tabular}

\begin{tabular}{|c|c|c|}
\hline & $\mathrm{N}$ & 104 \\
\hline \multirow[t]{3}{*}{ Y1.6 } & $\begin{array}{l}\text { Pearson } \\
\text { Correlation }\end{array}$ & .461 \\
\hline & Sig. (2-tailed) & .000 \\
\hline & $\mathrm{N}$ & 104 \\
\hline \multirow[t]{3}{*}{ Y1.7 } & $\begin{array}{l}\text { Pearson } \\
\text { Correlation }\end{array}$ & .393 \\
\hline & Sig. (2-tailed) & .000 \\
\hline & $\mathrm{N}$ & 104 \\
\hline \multirow[t]{3}{*}{ Y1.8 } & $\begin{array}{l}\text { Pearson } \\
\text { Correlation }\end{array}$ & .380 \\
\hline & Sig. (2-tailed) & .000 \\
\hline & $\mathrm{N}$ & 104 \\
\hline \multirow[t]{3}{*}{ Y1.9 } & $\begin{array}{l}\text { Pearson } \\
\text { Correlation }\end{array}$ & $.400^{*}$ \\
\hline & Sig. (2-tailed) & .000 \\
\hline & $\mathrm{N}$ & 104 \\
\hline \multirow[t]{3}{*}{ Y1.10 } & $\begin{array}{l}\text { Pearson } \\
\text { Correlation }\end{array}$ & .384 \\
\hline & Sig. (2-tailed) & .000 \\
\hline & $\mathrm{N}$ & 104 \\
\hline \multirow[t]{3}{*}{ Y } & $\begin{array}{l}\text { Pearson } \\
\text { Correlation }\end{array}$ & 1 \\
\hline & Sig. (2-tailed) & \\
\hline & $\mathrm{N}$ & 104 \\
\hline
\end{tabular}

Sumber : Hasil Penelitian (2017)

Tabel 4. Hasil Pengujian Instrumen Variabel $Y$

\begin{tabular}{|c|c|c|c|}
\hline Item & $\mathbf{R}$ & Sig. & Keterangan \\
\hline Y1.1 & 0.345 & 0.000 & Valid \\
\hline Y1.2 & 0.576 & 0.000 & Valid \\
\hline Y1.3 & 0.651 & 0.000 & Valid \\
\hline Y1.4 & 0.587 & 0.000 & Valid \\
\hline Y1.5 & 0.592 & 0.000 & Valid \\
\hline Y1.6 & 0.461 & 0.000 & Valid \\
\hline Y1.7 & 0.393 & 0.000 & Valid \\
\hline Y1.8 & 0.380 & 0.000 & Valid \\
\hline Y1.9 & 0.400 & 0.000 & Valid \\
\hline Y1.10 & 0.384 & 0.000 & Valid \\
\hline Sumber
\end{tabular}

Sumber : Hasil Penelitian (2017)

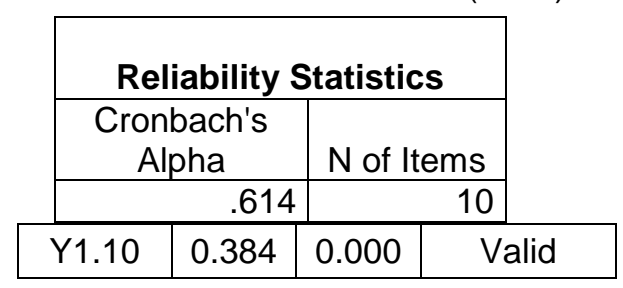

Dari tabel 4 diatas, didapatkan bahwa semua item dari variabel $Y$ sudah valid. Terlihat dari nilai correlation $(r)$ untuk masing-masing item valid yang lebih besar dari nilai $r$ tabel sebesar 0.194, atau dengan nilai signifikansi yang lebih kecil dari 0.05. Oleh karena itu, maka dapat diambil 10 item sudah valid dan dapat digunakan untuk penelitian selanjutnya. 


\subsection{Uji Reabilitas}

Reabilitas analisis adalah analisis yang banyak digunakan untuk mengetahui konsistensi alat ukur yang menggunakan skala, kuesioner atau angket. (Priyatno, 2009)

Pengujian reabilitas dilakukan untuk menguji tingkat ketetapan suatu instrumen akurat atau tidak. Dari data kuesioner yang diperoleh maka dapat dicari reliabilitasnya dengan menggunakan rumus Cronbach's Alpha.Instrumen dapat dikatakan handal (reliabel) bila memiliki koefisien keandalan reliabilitas sebesar 0.6 atau lebih.Uji reliabilitas yang digunakan adalah dengan Cronbach's Alpha.Bila alpha lebih kecil dari 0.6 maka dinyatakan tidak reliabel dan sebaliknya dinyatakan reliabel. Hasil pengujian reliabilitas terhadap semua variabel ditunjukkan tabel di bawah ini:

Tabel 5. Uji Reabilitas Instrumen Variabel X

\begin{tabular}{|c|c|c|c|}
\hline \multicolumn{4}{|c|}{ Case Processing Summary } \\
\hline & & $\mathrm{N}$ & $\%$ \\
\hline \multirow[t]{3}{*}{ Cases } & Valid & 104 & 100.0 \\
\hline & Excluded $^{\mathrm{a}}$ & 0 & .0 \\
\hline & Total & 104 & 100.0 \\
\hline
\end{tabular}

a. Listwise deletion based on all variables in the procedure.

\begin{tabular}{|r|r|}
\hline \multicolumn{2}{|c|}{ Reliability Statistics } \\
\hline $\begin{array}{c}\text { Cronbach's } \\
\text { Alpha }\end{array}$ & N of Items \\
\hline .703 & 10 \\
\hline
\end{tabular}

Tabel 6 Uji Reabilitas Instrumen Variabel $Y$

\begin{tabular}{|c|c|c|c|}
\hline \multicolumn{4}{|c|}{ Case Processing Summary } \\
\hline & & $\mathrm{N}$ & $\%$ \\
\hline \multirow[t]{3}{*}{ Cases } & Valid & 104 & 100.0 \\
\hline & Excluded $^{\mathrm{a}}$ & 0 & .0 \\
\hline & Total & 104 & 100.0 \\
\hline
\end{tabular}

Tabel 7. Hasil Pengujian Reliabilitas Variabel

\begin{tabular}{|c|c|c|c|}
\hline Variabel & Butir & $\begin{array}{c}\text { Koefisien } \\
\text { Alpha }\end{array}$ & Keterangan \\
\hline $\mathrm{X}$ & 10 & 0.703 & Reliabel \\
\hline $\mathrm{Y}$ & 10 & 0.614 & Reliabel \\
\hline \multicolumn{2}{|c|}{ Sumber : Hasil Penelitian (2017) } \\
\cline { 2 - 2 }
\end{tabular}

Berdasarkan tabel 7 di atas dapat diketahui bahwa variabel $X$ dan $Y$ memiliki nilai koefisien Cronbach's Alpha lebih besar dari 0.6 sehingga dapat dikatakan variabel yang digunakan dalam penelitian ini sudah reliabel atau dapat dihandalkan dan dapat dilanjutkan ke analisis selanjutnya.

\subsection{Uji Normalitas}

Uji Normalitas bertujuan untuk menguji apakah dalam regresi variabel terikat dan variabel bebas keduanya mempunyai distribusi normal atau tidak. Model regresi dapat dikatakan memenuhi asumsi normalitas jika residual yang diperoleh dari model regresi berdistribusi normal. Hipotesis yang digunakan dalam pengujian adalah:

$\mathrm{H}_{0}$ : Sebaran residual berdistribusi normal $\mathrm{H}_{1}$ : Sebaran residual tidak berdistribusi normal

Untuk menguji asumsi ini, dapat digunakan grafik histogram dan Normal P-P plot serta One-Sample KolmogorovSmirnov Test sebagai berikut:

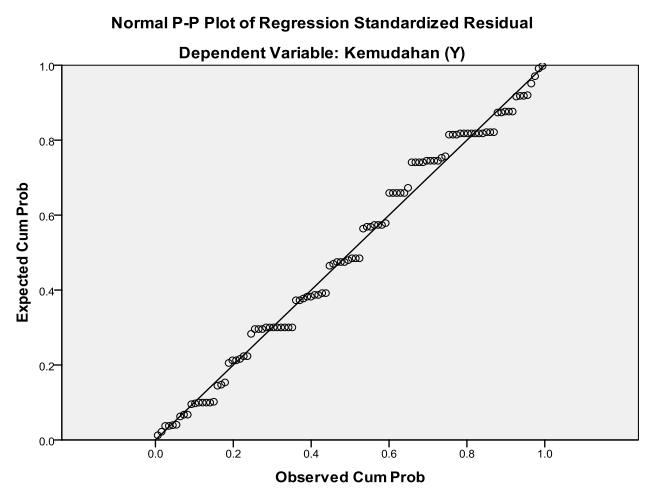

Gambar 2. Grafik Histogram Uji NormalitasAntara Variabel Persepsi Pengaruh Kegunaan $(X)$ dengan Variabel Persepsi Kemudahan

Sumber : Hasil Penelitian (2017)

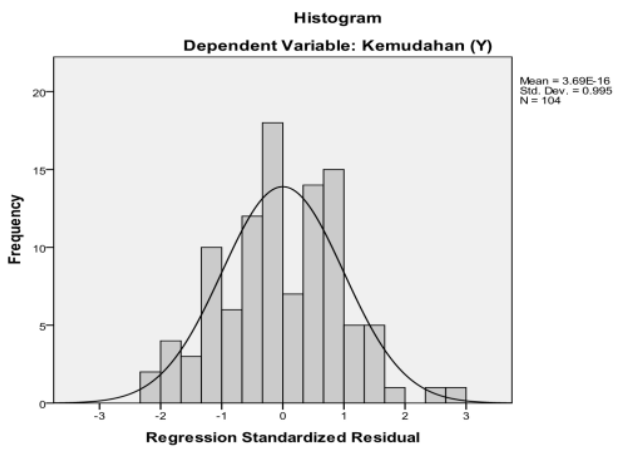

Gambar 3. Normalitas Probability Plot Antara Variabel Persepsi Kemanfaatan Pengguna $(X)$ dengan Variabel Persepsi Kemudahan $(Y)$

Sumber : Hasil Penelitian (2017)

Tabel 8. Uji one sampleKolmogorovSmirnovUntuk Persepsi Kemanfaatan Pengguna terhadap Persepsi Kemudahan

\begin{tabular}{|c|c|}
\hline Residual & Signifikansi \\
\hline Model 1 & 0.394 \\
\hline \multicolumn{2}{|c|}{ Sumber : Hasil Penelitian (2017) }
\end{tabular}


Dari Histogram pada gambar 2 menunjukkan bahwa diagram batang mengikuti kurva normal yang terbentuk dan dari grafik P-P plot pada gambar 3 didapatkan bahwa data observasi berada di sekitar garis diagonal, dan dari tabel 8 diatas, didapatkan nilai signifikansi dari pengujian one sample Kolmogorov-Smirnov sebesar 0.394 lebih besar dari a (0.05). Berdasarkan ketiga pengujian tersebut, diambil keputusan terima $\mathbf{H}_{0}$ yang artinya sebaran residual berdistribusi normal (asumsi tepenuhi).

\subsection{Uji Linearitas}

Uji lineritas bertujuan untuk menguji apakah bentuk hubungan antara variabel bebas dan variabel terikat adalah linier atau tidak. Hubungan kedua variabel dikatakan linier apabila nilai signifikansi uji lebih kecil dari alpha yang digunakan.Hasil pengujian disajikan berikut ini.

Tabel 9. Uji Linieritas dengan Curve Fit

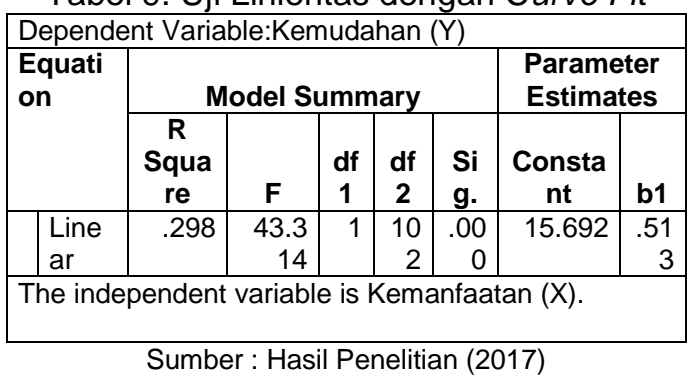

Tabel 10. Hasil Pengujian Linieritas Dengan

\begin{tabular}{|c|l|l|}
\multicolumn{3}{|c}{ Curve Fit } \\
\hline Variabel & Signifikansi & $\begin{array}{c}\text { Keteranga } \\
\mathbf{n}\end{array}$ \\
\hline X1 terhadap Y1 & 0.000 & Linier \\
\hline
\end{tabular}

Sumber : Hasil Penelitian (2017)

Pengujian asumsi linieritas pada tabel 9 dilakukan dengan metode Curve Fit dengan melihat bentuk hubungan antara variabel bebas dan variabel terikat. Hasil pengujian menunjukkan bahwa nilai signifikansi pada hubungan $X \rightarrow Y$ sebesar 0.000. Dapat disimpulkan bahwa nilai signifikansi untuk 1 pasang hubungan tersebut lebih kecil dari a 5\%, sehingga dapat disimpulkan bahwa terdapat hubungan linier antar variabel yang digunakan.

\subsection{Analisis Regresi Sederhana}

Analisis regresi sederhana digunakan untuk menguji bagaimana variabel dependen (variabel persepsi kemudahan) dapat diprediksi melalui variabel independen (variabel persepsi kemanfaatan pengguna).

Tabel 11.Hasil Uji Regresi

Variabel Entered atau Removed

\begin{tabular}{|l|c|c|c|c|}
\hline \multicolumn{2}{|c|}{ Model } & $\begin{array}{c}\text { Variables } \\
\text { Entered }\end{array}$ & $\begin{array}{c}\text { Variables } \\
\text { Removed }\end{array}$ & Method \\
\hline & 1 & $\begin{array}{c}\text { Kemanfaatan } \\
(\mathrm{X})^{\mathrm{a}}\end{array}$ & $\cdot$ & Enter \\
\hline \multicolumn{3}{|c|}{$\begin{array}{l}\text { a. All requested variables entered. } \\
\text { b. Dependent Variable: Kemudahan (Y) }\end{array}$} \\
\hline
\end{tabular}

Sumber : Hasil Penelitian (2017)

Tabel 12.Model Summary

\begin{tabular}{|c|c|c|c|c|}
\hline $\begin{array}{c}\text { Mode } \\
\text { I }\end{array}$ & $\mathbf{R}$ & R Square & $\begin{array}{l}\text { Adjusted } \\
\text { R Square }\end{array}$ & $\begin{array}{l}\text { Std. Error of } \\
\text { the Estimate }\end{array}$ \\
\hline $\mid 1$ & $.546^{\mathrm{a}}$ & .298 & .291 & 2.05979 \\
\hline \multicolumn{5}{|c|}{ a. Predictors: (Constant), Kemanfaatan $(\mathrm{X})$} \\
\hline \multicolumn{5}{|c|}{ b. Dependent Variable: Kemudahan (Y) } \\
\hline
\end{tabular}

Tabel 12 menjelaskan besarnya nilai korelasi atau hubungan (R) yaitu sebesar 0,546 dan dijelaskan besarnya presentase pengaruh variabel bebas terhadap variabel terikat yang disebut koefisien determinasi yang merupakan hasil dari pengkuadratan $R$. Dari output tersebut diperoleh koefisien determinasi (R2) sebesar 0,298, yang mengandung pengertian bahwa pengaruh variabel bebas (Persepsi kemanfaatan pengguna) terhadap variabel terikat (Persepsi kemudahan) adalah sebesar 29,8 \%, sedangkan sisanya diperoleh dari variabel yang lain.

Tabel 13. Hasil Pengujian dengan Annova

\begin{tabular}{|c|c|c|c|c|c|}
\hline Model & $\begin{array}{l}\text { Sum of } \\
\text { Squares }\end{array}$ & Df & $\begin{array}{l}\text { Mean } \\
\text { Square }\end{array}$ & $\mathrm{F}$ & Sig \\
\hline $\begin{array}{l}1 \\
\text { Regressi }\end{array}$ & 183.770 & 1 & 183.770 & $\begin{array}{r}43.3 \\
14\end{array}$ & $\begin{array}{l}.00 \\
0^{*}\end{array}$ \\
\hline Residual & 432.759 & $\begin{array}{l}1 \\
0 \\
2\end{array}$ & 4.243 & & \\
\hline Total & 616.529 & $\begin{array}{l}1 \\
0 \\
3\end{array}$ & & & \\
\hline
\end{tabular}

a. Predictors : (Constant), Kemanfaatan (X)

b. Dependent Variabel : Kemudahan $(Y)$ Sumber : Hasil Penelitian (2017)

Tabel 13 menjelaskan apakah ada pengaruh yang nyata (signifikan) variabel persepsi kemanfaatanpengguna (X) terhadap variabel persepsi kemudahan $(\mathrm{Y})$. Dari tabel di atas terlihat bahwa $\mathrm{F}$ hitung $=$ 43,314 dengan tingkat signifikansi atau probabilitas $0,000<0,005$, maka model regresi dapat dipakai untuk memprediksi variabel persepsi kemudahan. 


\subsection{Analisis Regresi Linier Sederhana}

Analisis regresi yang berguna untuk mendapatkan pengaruh variabel $X$ (persepsi kemanfaatan) terhadap variabel $Y$ (persepsi kemudahan).Dalam pengolahan data dengan menggunakan analisis regresi linier sederhana, dilakukan beberapa tahapan untuk mencari hubungan antara variabel independen dan dependen. Berdasarkan hasil pengolahan data dengan menggunakan software SPSS 18 didapatkan ringkasan seperti berikut:

Tabel 14. Uji Regresi Linier Sederhana

\begin{tabular}{|c|c|c|c|c|}
\hline Variabel & $B$ & $\begin{array}{l}F_{\text {hitun }} \\
g\end{array}$ & $\begin{array}{l}\text { Signifika } \\
\text { nsi }\end{array}$ & $\begin{array}{l}\text { Keterang } \\
\text { an }\end{array}$ \\
\hline Konstanta & $\begin{array}{l}15.6 \\
92 \\
\end{array}$ & & & \\
\hline $\begin{array}{l}\mathrm{X}(\text { persepsi } \\
\text { kemanfaat } \\
\text { an) }\end{array}$ & $\begin{array}{l}0.51 \\
3\end{array}$ & $\begin{array}{l}43.3 \\
14\end{array}$ & 0.000 & Signifikan \\
\hline $\begin{array}{l}\text { A } \\
\text { Koefisien D } \\
\text { F-tabel }\left(F_{1}\right.\end{array}$ & $\begin{array}{l}\text { ermin } \\
0.05)\end{array}$ & $\left.R^{2}\right)$ & $\begin{array}{l}0.050 \\
0.298 \\
3.934 \\
\end{array}$ & \\
\hline
\end{tabular}

Sumber : Hasil Penelitian (2017)

Berdasarkan tabel 14 di atas, diperoleh model regresi sebagai berikut :

$$
Y=15.692+0.513 X+e_{i}
$$

Interpretasi model regresi tersebut adalah sebagai berikut :

1. $\beta_{0}=15.962$. Koefisien regresi ini menunjukkan bahwa tanpa adanya pegaruh dari variabel-variabel bebas terhadap variabel $\mathrm{Y}$, maka skor total dari variabel $Y$ sudah meningkat (variabel persepsi kemudahan sudah meningkat sebelumnya).

2. $\beta_{2}=0.513$. Koefisien regresi yang bernilai positif memiliki arti pengaruh searah antara variabel $X$ (persepsi kemanfaatan) terhadap variabel $Y$ (persepsi kemudahan), yang artinya apabila terjadi peningkatan pada variabel $\mathrm{X}$, maka variabel $\mathrm{Y}$ akan meningkat, dan sebaliknya bila terjadi penurunan pada variabel $X$, maka variabel $Y$ akan menurun pula.

\section{A. Koefisien Determinasi $\left(\mathbf{R}^{2}\right)$}

Koefisien determinasi $\left(R^{2}\right)$ adalah ukuran ketepatan atau kecocokan garis regresi yang diperoleh dari hasil pendugaan parameter berdasarkan contoh. Selain itu, koefisien determinasi juga dapat digunakan untuk mengukur besar proporsi keragaman total di sekitar nilai tengah yang dapat dijelaskan oleh garis regresi.

Besarnya kontribusi dari variabel independen terhadap variabel dependen, berdasarkan hasil perhitungan pada tabel IV.7 dengan nilai koefisien determinasi ( $R$ Square) sebesar 0.298. Hasil tersebut menjelaskan sumbangan atau kontribusi dari variabel $X$ (persepsi kemanfaatan) yang disertakan dalam persamaan regresi terhadap variabel $Y$ (persepsi kemudahan) adalah sebesar $29.8 \%$, sedangkan $70.2 \%$ lainnya disumbangkan oleh variabel lainnya yang tidak dimasukkan ke dalam persamaan ini.

\section{B. Uji hipotesis (uji-F)}

Pengujian model regresi ini digunakan untuk mengetahui apakah variabel independen memiliki pengaruh yang signifikan terhadap variabel dependen.

Hipotesis:

$\mathrm{H}_{0}$ :tidak terdapat pengaruh yang signifikan antara variabel independentterhadap variabel dependen;

$\mathrm{H}_{1}$ : terdapat pengaruh yang signifikan antara variabel independentterhadap variabel dependen.

Pengambilan keputusan :

$\mathrm{H}_{0}$ ditolak jika $\mathrm{F}_{\text {hitung }}>\mathrm{F}_{\text {tabel}}$, atau nilai signifikansi $<\alpha$

$\mathrm{H}_{0}$ diterima jika $\mathrm{F}_{\text {hitung }}<\mathrm{F}_{\text {tabel }}$, atau nilai signifikansi $>\alpha$

Berdasarkan tabel 14 didapatkan bahwa variabel $X$ (persepsi kemanfaatan) memiliki statisitik uji $F$ sebesar 43.314dengan signifikansi sebesar 0.000 . Nilai statistik uji $F_{\text {hitung }}$ tersebut lebih besar daripada $F_{\text {tabel }}$ $(43.314$ > 3.934) dan nilai signifikan $\mathrm{F}$ lebih kecil dari $\alpha$ (0.05). Pengujian ini menunjukkan bahwa $\mathbf{H}_{\mathbf{0}}$ ditolak sehingga dapat disimpulkan bahwa variabel $X$ (persepsi kemanfaatan) berpengaruh secara signifikan (nyata) terhadap variabel Y (persepsi kemudahan). Atau dengan kata lain variabel persepsi kemanfaatan memiliki pengaruh yang nyata dan cukup besar terhadap variabel persepsi kemudahan dalam penelitian ini.

\section{Kesimpulan}

Berdasarkan hasil penelitian dan pembahasan dapat diambil kesimpulan bahwa dari hasil uji validitas menunjukkan semua item pertanyaan sudah valid, dibuktikan dengan lebih besarnya nilai (r) hitung dari nilai $(r)$ tabel sebesar 0.194, hasil uji reliabilitas diperoleh nilai koefisien variabel $x$ sebesar 0.703 dan nilai koefisien variabel y sebesar 0.614 sehingga kedua variabel reliabel, dibuktikan bahwa variabel $x$ dan y memiliki nilai koefisien Cronbach's Alpha lebih besar dari 0.6.

Hasil uji normalitas didapatkan nilai signifikansi sebesar 0.394 dari pengujian One Sample Kolmogrov-Smirnov, hasil uji 
linearitas terdapat hubungan linier antar variabel, dibuktikan bahwa hubungan variabel $x$ terhadap variabel $y$ nilai signifikansi sebesar 0.000 dan diperoleh nilai frekuensinya sebesar 43.314

Hasil koefisien determinasi bahwa persamaan regresi (persepsi manfaat) terhadap variabel (persepsi kemudahan) memiliki pengaruh antar variabel sebesar $29.8 \%$, sedangkan sisanya diperoleh dari variabel yang lain hasil uji hipotesis analisis varians untuk regresi dengan membandingkan nilai signifikansi dengan probabilitas 0,05 diperoleh nilai Fhitung = 43,314 dengan nilai signifikansi $0,000<0,05$. Maka dapat diputuskan bahwa hipotesis penelitian $\left(\mathrm{H}_{1}\right)$ yang menyatakan terdapat pengaruh yang signifikan positif persepsi kemanfaatan pengguna terhadap persepsi kemudahan penggunaan internet banking bagi para nasabah dan hipotesis $\left(\mathrm{H}_{0}\right)$ ditolak, hasil penelitian menunjukkan bahwa variabel persepsi kemanfaatan penggunaan internet memiliki pengaruh secara langsung terhadap persepsi kemudahan penggunaan internet dalam bertransaksi bagi nfasabah Bank BRI KCP Unit Jagakarsa. Semakin banyak manfaat yang dirasakan para nasabah, maka akan mempengaruhi rasa kemudahan bagi nasabah setiap bertransaksi menggunakan internet banking.

Saran untuk penelitian kedepan ditambahkan variabel penelitian yang ada pada TAM, menggunakan metode yang lain selain TAM dan jumlah sampel yang lebih besar yaitu nasabah bank BRI KCP per wilayah atau seluruh Indonesia.

\section{Referensi}

Ahmad, \& Pambudi, B. S. (2014). Pengaruh Persepsi Manfaat, Persepsi Kemudahan, Keamanan dan Ketersediaan Fitur TerhadapMinat Ulang Nasabah Bank Dalam Menggunakan Internet Banking (Studi Kasus Pada Program Layanan Internet Banking). Jurnal Studi Manajemen Vol. 8 No.1.

Arikunto, S. (2010). Prosedur Penelitian, Suatu Pendekatan Praktik. Jakarta: PT. Rineka Cipta.

Chan, S., \& M, L. (2004). Understanding Internet Banking Adoption and use Behaviour. Journal of Global Information Management .
Devi, \& Suartana. (2014). Analisis Technology Acceptance Model (TAM) Terhadap Penggunaan Sistem Informasi Di Nusa Dua Beach Hotel dan SPA ISSN: 23028558. E-Jurnal Akuntansi Universitas Udayana.

Gunawan, A. (2014). Aplikasi Technology Acceptance Model Pada Minat Nasabah Untuk Menggunakan Internet Banking. Jurnal Nominal Vol 3 No.2.

Hartono, J. (2007). Metodologi Penelitian Bisnis: Salah Kaprah dan Pengalaman-Pengalaman. Yogyakarta: BPFE.

Kasmadi, \& Sunariah, N. S. (2014). Panduan Modern Penelitian Kuantitatif. Bandung: Alfabeta.

Priyatno, D. (2009). 5 Jam Belajar Olah Data dengan SPSS 17. Yogyakarta: Andi Offset.

Sanusi, A. (2000). Prospek Internet Banking di Era Millenium III. Jakarta: Elex Media Komputindo.

Siregar, S. (2015). Statistik Parametrik Untuk Penelitian Kuantitatif. Jakarta: Bumi Aksara.

Sugiyono. (2014). Metode Penelitian Kuantitatif Kualitatif dan $R$ \& $D$. Bandung: Alfabeta.

Sugiyono. (2010). Statistika Untuk Penelitian. Bandung: CV. Alfabeta. 